\title{
Profil Berpikir Krtitis Siswa SMP Dalam Memecahkan Masalah Matematika Berdasarkan Gaya Kognitif.
}

\author{
(The Profile of Junior High School Students' Critical Thinking in Solving Mathematics \\ Problems based on Their Cognitive Styles)
}

\author{
La Saudi ${ }^{1}$, Muhammad Sudia ${ }^{2}$, Mustamin Anggo ${ }^{2}$ \\ ${ }^{1}$ Alumnus Prodi Pendidikan Matematika PPs Universitas Halu Oleo \\ ${ }^{2}$ Dosen Pendidikan Matematika FKIP dan PPS Universitas Halu Oleo Co-author: \\ muhammad_matematika@yahoo.co.id
}

\begin{abstract}
Abstrak: Penelitian ini bertujuan untuk mendeskripsiskan profil berpikir kritis siswa berdasarkan gaya kognitif reflektif dan impulsive. Peneliti ini memberikan tes Pengelompokan gaya kognitif kepada siswa kelas VIII SMP Negeri 5 Kendari. Untuk mendeskripsikan profil berpikir kritis siswa secara kualitatif dipilih dua siswa terdiri satu (1) impuslif dan satu (1) siswa reflektif, dengan pada setiap langkah pemecahan masalah Polya mempertimbangkan kemampuan komunikasi siswa. Dari hasil penelitian diperoleh temuan profil berpikir kritis siswa reflektif pada setiap pentahapan Polya yaitu semua memenuhi kriteria indikator berpikir kritis sebagai berikut : (1) pada kriteria focus memahami permasalahan dan memahami pertanyaan pada soal terkait sistem persamaan linear dua variabel dan mampu membuat keputusan dengan pemisalan menggunakan variabel $\mathrm{x}$ dan $\mathrm{y}$, (2) dalam setiap langkah pengambilan keputusan dengan alasan (reason) yang relevan, (3) kesimpulan (inference) yang dibuat sesuai dengan tujuan soal dan alasan yang digunakan tepat, (4) pada kriteria situation, siswa mengetahui situasi dengan baik, (5) memberikan penjelasan lebih lanjut (clarity) dari kesimpulan, (6) untuk overview, tidak melakukan pengecekan kembali terhadap jawaban yang diperoleh.
\end{abstract}

Kata kunci: Berpikir kritis, Pemecahan Masalah Matematika, Gaya Kognitif.

\begin{abstract}
This study aimed to describe the profile of students' critical thinking based on reflective and impulsive cognitive style. The study administered a test designed to group cognitive style to students of class VIII at SMP Negeri 5 Kendari. To describe qualitatively the profile of students' critical thinking, one impulsive student and one reflective student were chosen and taught to solve mathematics problem using Polya stages by considering their communicative ability. Result of the study showed that the profile of reflective students' critical thinking in each stage of Polya has included all criteria of critical thinking, as follows: (1) in the focus stage, the student was able to understand the problem and the question about two-variable linear equation system and was able to make a decision with analogy using $\mathrm{x}$ and $\mathrm{y}$ variable; (2) in each step, decision was made based on a relevant reason (reason); (3) the conclusion (inference) made was relevant with the objective of the question and correct reason; (4) in terms of situation, the student knew the situation well; (5) the student provided further explanation (clarity) to the conclusion; (6) in terms of overview, the student did recheck the answer obtained.
\end{abstract}

Keywords: Critical Thinking, Solving Mathematics Problems, Cognitive Style

\section{PENDAHULUAN}

Pemecahan masalah mempunyai hubungan timbal balik dengan berpikir kritis (Sabandar, 2009). Belajar dengan pemecahan masalah akan melatih siswa terampil dalam berpikir. Berpikir kritis diperlukan dalam pemecahan masalah, karena dalam memecahkan masalah, berpikir kritis memberikan arahan yang tepat dalam berpikir dan bekerja serta membantu menemukan keterkaitan faktor yang satu dengan yang lainya secara akurat. Dalam pembelajaran matematika siswa yang berpikir kritis akan terbantu dalam memecahkan masalah. Sebaliknya seorang siswa yang terbiasa memecahkan masalah matematika akan cenderung berpikir kritis. Lebih lanjut hubungan antara pemecahan masalah dan berpikir kritis didukung oleh Snyder \& Snyder (2008); Saurino (2008) yang dapat disimpulkan bahwa ada peningkatan 
berpikir kitis terutama yang berkaitan dengan pemecahan masalah.

Setiap orang pasti pernah mengalami masalah dalam kehidupannya. Masalah dan pemecahan masalah merupakan bagian dari proses kehidupan yang harus dilalui bagi setiap orang dan merupakan sarana pematangan untuk menjamin keberadaannya, baik sebagai individu maupun sebagai bagian dari lingkungannya (Sudia, 2013). Demikian juga kemampuan memecahkan masalah merupakan keterampilan dasar yang harus dimiliki setiap orang agar dapat menempuh kehidupannya dengan lebih baik (Kirkley, 2003).

Stanic \& Kilpatrick mendefinisikan masalah sebagai suatu keadaan pada saat seseorang melakukan tugasnya yang tidak ditemukan pada waktu sebelumnya. Hal ini menunjukkan bahwa suatu tugas merupakan masalah bergantung kepada individu dan waktu. Artinya, suatu tugas merupakan masalah bagi seseorang, tetapi mungkin bukan merupakan masalah bagi orang lain. Demikian pula suatu tugas merupakan masalah bagi seseorang pada suatu saat, tetapi bukan merupakan masalah lagi bagi orang itu pada saat berikutnya, bila orang itu telah mengetahui cara atau prosedur mendapatkan pemecahan masalah tersebut. Hal yang sama Schoenfeld (1985) mendefinisikan bahwa: "problem is that problem solving is relative." Masalah dalam pemecahan masalah adalah relatif.

Untuk menentukan suatu situasi merupakan masalah atau tidak, adalah dengan melihat bagaimana seseorang bereaksi terhadap situasi tersebut. Apabila tidak ada strategi yang dengan mudah ditemukan, maka situasi itu merupakan masalah, dan sebaliknya bila strategi dapat diterapkan secara normal oleh seseorang berlaku pada situasi yang mirip dengan situasi yang diberikan, maka hal tersebut bukan merupakan masalah. (Dossey dkk., 2006). Sejalan dengan yang dikemukakan Dossey dkk. di atas, Cooney dkk. (1975 ) mengatakan bahwa: " . . f for a question tobe a problem, it must present a challenge that can not be resolved by some routine procedures known to the student." Pertanyaan merupakan masalah, jika pertanyaan itu menghadirkan suatu tantangan yang tidak dapat dipecahkan dengan suatu prosedur rutin yang sudah diketahui siswa. Hal yang sama juga dikatakan Shadiq (2004) bahwa suatu pertanyaan akan menjadi masalah hanya jika pertanyaan itu menunjukkan adanya suatu tantangan yang tidak dapat dipecahkan melalui suatu prosedur rutin yang sudah diketahui sipelaku, maka untuk menyelesaikan suatu masalah diperlukan waktu yang relatif lebih lama dari proses pemecahan soal rutin.

Ada beberapa variasi atau sifat dari masalah, yaitu pada (1) pengetahuan yang diperlukan untuk menyelesaikan masalah; (2) bentuk penyajiannya; (3) proses yang dilakukan dalam pemecahan masalah (Jonassen, 2004). Berdasarkan hal tersebut, maka dapat dijumpai adanya masalah yang disajikan secara sederhana dan pemecahannya dapat dilakukan dengan menggunakan pengetahuan dan proses yang tidak terlalu rumit, tetapi juga ada masalah yang lebih kompleks, yang memerlukan pengetahuan dan keterampilan serta melibatkan aktivitas yang tinggi dalam memecahkannya.

Pada umumnya masalah matematika dapat dibedakan menjadi dua bagian, yaitu masalah rutin dan masalah tidak rutin (Anonim, 2007). Masalah rutin adalah masalah yang merupakan latihan biasa yang dapat diselesaikan dengan prosedur yang sudah lazim digunakan, sedangkan masalah tidak rutin adalah masalah yang untuk menyelesaikannya diperlukan pemikiran lebih lanjut karena prosedurnya tidak sejelas masalah rutin atau dengan kata lain, masalah tidak rutin menyajikan situasi baru yang belum pernah dijumpai sebelumnya. Dalam situasi baru yang dimaksud ada tujuan yang jelas ingin 
dicapai tetapi cara pencapaiannya tidak segera muncul dalam benak siswa.

Butts (1980) menyebutkan bahwa masalah dalam matematika dikelompokkan menjadi lima bagian, yaitu: (1) recognition exercises; (2) algorthmicexercises; (3) application problem; (4) open-search; (5) problem situation. Masalah yang dikategorikan sebagai recognition exercises adalah masalah-masalah yang berkaitan dengan ingatan, misalnya fakta, konsep, definisi dan teorema. Masalah yang dikategorikan sebagai algorithmic exercises adalah masalah-masalah yang berkaitan dengan penggunaan langkah demi langkah suatu prosedur atau cara tertentu. Masalah yang dikategorikan sebagai application problem adalah masalah-masalah yang termasuk di dalamnya penggunaan atau penerapan algoritma. Masalah yang dikategorikan sebagai open-search problem adalah masalah-masalah pembuktian, menemukan sesuai dengan persyaratan tertentu. Masalah yang dikategorikan sebagai problem situation adalah masalah-masalah yang penyajiannya berkaitan dengan situasi nyata atau kehidupan sehari-hari.

Masalah matematika dalam penelitian ini adalah masalah tidak rutin yang dikategorikan sebagai problem situation, karena masalah yang diberikan tidak pernah dijumpai sebelumnya oleh siswa dan merupakan masalah-masalah nyata atau masalah yang berkaitan dengan kehidupan sehari-hari.

Berpikir kritis sangat penting untuk berparitipasi secara efektif dalam masyarakat yang demokratis berkaitan proses membuat suatu keputusan di tempat kerja, kepemimpinan, pengadilan yang mempunyai efek langsung terhadap kesuksesan profesinya (Kolelioglu \& Gulbahar, 2014).

Santrock (2007) mendefinisikan berpikir kritis adalah: Critical thinking involves grasping the deeper meaning of problem, keeping an open mind about diffrent appoaches and perspective, not accepting on faith what other people and books tell you, and thinking reflectively rahter than accepting the first idea that comes to mind. Berpikir kritis adalah cara berpikir refleksi yang masuk akal atau berdasarkan nalar yang di fokuskan untuk menentukan apa yang harus diyakini dan dilakukan (Ennis, 1996). Lau (2011: 1) mendefinisikan berpikir kritis sebagai "thinking clearly and rationally". It involves thinking precisely and systematically, and following te rules of logic and scientific reasoning, among other things". Berpikir kritis adalah suatu cara berpikir dan suatu kumpulan keterampilan yang mendorong sebuah informasi, kesadaran dan dianggap pendekatan logis untuk memutuskan apa yang harus dipercaya atau dilakukan (Kalelioglu \& Gulbahar, 2014).

Sukmadinata

mengungkapkan bahwa berpikir kritis adalah suatu kecakapan nalar secara teratur, kecakapn sistematis dalam menilai, memecahkan masalah, menarik keputusan, memberikan keyakinan, menganalisis asumsi, dan pencarian ilmiah. Menurut Johnson (2009:1) berpikir kritis merupakan kemampuan esensial yang harus dimiliki oleh siswa untuk memecahkan masalah. Sedangkan menurut Glazer (2001) berpikir kritis dalam matematika adalah kemampuan dan disposisi untuk melibatkan pengetahuan sebelumnya, penalaraan matematis, dan strategi kognitif untuk menggeneralisasi, membuktikan atau mengevaluasi situasi matematis yang kurang dikenal dalam cara yang reflektif. Dari berbagai definisi di atas dapat disimpulkan bahwa berpikir kritis merupakan berpikir yang terjadi dalam sistem kognitif dengan membandingkan beberapa pengetahuan yang sudah ada dalam pikiran yang bertujuan untuk menyelesaikan suatu permasalahan dengan memutuskan pengetahuan yang lebih tepat digunakan untuk memecahkan masalah. Dalam berpikir kritis menuntut adanya usaha serta 
memerlukan adanya rasa perduli tentang keakurasian dan adanya kemauan dan tidak mudah menyerah ketika menghadapi tugas yang sulit (Sternberg, dkk 2007).

Ada enam unsur dasar yang perlu dipertimbangkan dalam berpikir kritis, yaitu fokus, reason, inference, situation, clarity, overviev (Ennis, 1996). Dengan kata lain fokus, alasan, kesimpulan, situasi, kejelasan dan pemeriksaan secara keseluruhan harus muncul manakalah seseorang dikatakan sedang berada pada keadaan berpikir kritis. Jika keseluruhan unsur ini telah dipertimbangkan secara matang maka orang dapat membuat keputusan yang dapat terkait dengan pemecahan masalah. Dilihat secara mendalam, unsur-unsur berpikir kritis ini tercermin dalam langkah pemecahan masalah Polya (Sabandar, 2009).

Setiap siswa mempunyai gaya kognitif masing-masing. Perbedaan gaya kognitif menarik perhatian peneliti karena peneliti ingin mengetahui profil berpikir kritia siswa yang berbeda gaya kognitifnya dalam memecahkan masalah matematika. Banyak para ahli yang telah mendefinisikan pengertian gaya kognitif, misalnya: Heineman mengemukakan beberapa pengertian gaya kognitif sebagai berikut: (1) gaya kognitif merujuk kepada cara yang lebih disukai individu dalam mengatur dan memproses informasi; (2) gaya kognitif biasanya

\section{METODE PENELITIAN}

Penelitian ini adalah eksploratif yang menggunakan pendekatan deskriptifkualitatif. Subjek dalam penelitian ini ada 2 (dua) orang, yaitu siswa yang bergaya kognitif impulsif dan siswa yang bergaya kognitif reflektif. Cara memperoleh subjek penelitian adalah dengan melakukan pengetesan gaya kognitif, kemudian mengambil dua orang yang memiliki gaya kognitif impulsif dan yang bergaya kognitif reflektif, yaitu mengambil dua orang yang berbeda secara digambarkan sebagai suatu dimensi kepribadian yang mempengaruhi sikap, nilai dan interaksi sosial; (3) gaya kognitif meliputi pola perilaku konsisten individu dalam hal cara berpikir, mengingat dan memecahkan masalah. Hal yang sama juga dikemukakan Riding, Glass dan Douglas (1993) bahwa gaya kognitif mengacu pada kecenderungan dan konsistensi individu dalam memahami, mengingat, mengorganisasikan, berpikir dan pemecahan masalah.

Dari beberapa pengertian gaya kognitif yang dikemukakan di atas, pada dasarnya menitikberatkan pada karakteristik konsistensi individu (tidak berarti karakteristik individu tidak dapat diubah) dalam hal cara berpikir, mengingat, memproses informasi dan memecahkan masalah. Dari pengertian gaya kognitif ini juga terlihat bahwa antara gaya kognitif dan pemecahan masalah memiliki keterkaitan, karena keberhasilan seseorang dalam memecahkan masalah akan sangat ditentukan bagaimana cara orang itu berpikir, mengingat konsepkonsep sebelumnya yang terkait dengan masalah yang diberikan dan bagaimana memproses informasi untuk mendapatkan solusi yang tepat. Oleh sebab itu dalam pembelajaran pemecahan masalah perlu memperhatikan gaya kognitif siswa.

ekstrim, baik berdasarkan waktu maupun berdasarkan kesalahan yang dilakukan siswa pada saat pengetesan gaya kognitif. Instrumen dalam penelitian ini ada 2 (dua) macam, yaitu instrumen utama dan instrumen bantu. Instrumen uatama adalah peneliti sendiri, sedangkan instrumen bantu ada 3 (tigaq) macam. Yaitu tes gaya kognitif, tugas pemecahan masalah dan pedoman wawancara. 
HASIL PENELITIAN

1. Subjek Penelitian yang Bergaya

a. Tahap Memahami Masalah

Berdasarkan hasil analisis, SI memenuhi semua indikator kemampuan berpikir kritis pada saat memahami masalah, yaitu fokus terhadap hal-hal pokok dari masalah yang diberikan, dapat memberikan alasan terhadap apa yang dipahami pada masalah, dapat membuat kesimpulan dari apa yang diapahami pada masalah, memahami semua informasi pada masalah, mengklarifikasi apa yang dipahami dan memeriksa semua apa yang dituliskan sesuai yang dipahami pada masalah.

b. Tahap Membuat Rencana Pemecahan Masalah

Berdasarkan hasil analisis, SI tidak memenuhi semua indikator kemampuan berpikir kritis pada saat membuat rencana pemecahan masalah, yaitu awalnya SI belum fokus terhadap hal-hal pokok dari masalah yang diberikan, nanti setelah diberikan pertanyaan tambahan baru SI mulai fokus pada hal-hal pokok dari masalah yang diberikan, dapat memberikan alasan terhadap apa yang dipikirkan untuk menyelesaikan masalah, SI tidak dapat membuat kesimpulan dari apa yang dipikirkan untuk menjelesaikan masalah, SI memahami semua informasi yang dipikirkan pada masalah, SI mengklarifikasi apa yang dipikirkan dan SI memeriksa semua apa yang dipikirkan.

c. Tahap Melaksanakan Rencana Pemecahan Masalah

Berdasarkan hasil analisis SI tidak semua indikator kemampuan berpikir kritis dipenuhi oleh SI. Indikator kemampuan berpikir kritis yang dipenuhi adalah fokus menuliskan hal-hal utama atau pokok dari yang telah dipikirkan, mengatakan bahwa semua hal yang dipikirkan sudah ditulis. Indikator yang tidak terpenuhi adalah tidak bisa memberikan alasan tentang apa yang ditulis, tidak dapat menyimpulkan apa yang telah dituliskan, tidak mengklarifikasi tentang apa yang ditulis dan tidak mengecek semua hal yang ditulis.

d. Tahap Memeriksa Kembali Hasil Pemecahan Masalah

Berdasarkan hasil analisis, dalam memeriksa kembali hasil pemecahan masalah dapat SI tidak memenuhi semua indicator kemampuan berpikir kritis dipenuhi, Indikator kemampuan berpikir kritis yang dipenuhi adalah hanya fokus memeriksa semua hal yang ditulis, sedangkan indicator member alas an, menyimpulkan, melihat situasi lain yang diperiksa, mengklarifikasi hal yang diperiksa dan melakukan pengecekan kembali tidak dilakukan.

2. Subjek Penelitian yang Bergaya Kognitif Reflektif

a. Tahap Memahami Masalah

Berdasarkan hasil analisis, SR memenuhi semua indikator kemampuan berpikir kritis pada saat memahami masalah, yaitu fokus terhadap hal-hal pokok dari masalah yang diberikan, dapat memberikan alasan terhadap apa yang dituliskan pada masalah, dapat membuat kesimpulan dari apa yang diapahami pada masalah, memahami semua informasi pada masalah, mengklarifikasi apa yang dipahami dan memeriksa semua apa yang dituliskan sesuai yang dipahami pada masalah.

b. Tahap Membuat Rencana Pemecahan Masalah

Berdasarkan hasil analisis, SR memenuhi semua indikator kemampuan berpikir kritis dalam memecahkan masalah matematika pada tahap membuat rencana pemecahan masalah, yaitu indikator fokus memikirkan hal-hal pokok untuk menyelesaikan masalah, indikator reason atau memberi alasan mengenai hal-hal pokok yang dipikirkan, indikator inferensi atau menyimpulkan mengenai apa yang dipikirkan, indikator situation atau memikirkan hal lain yang yang terkait 
dengan masalah, indikator clariti atau mengklarifikasi tetntang apa yang dipikirkan dan indikator overview atau mengecek semua hal yang dipikirkan.

c. Tahap Melaksanakan Rencana Pemecahan Masalah

Berdasarkan hasil analisis SR memenuhi semua indikator kemampuan berpikir kritis dalam memecahkan masalah matematika pada tahap melaksanakan rencana pemecahan masalah, yaitu indikator fokus pada apa yang ditulis sesuai yang dipikirkan, indikator reason atau memberikaqqn alasan tentang apa yang ditulis, indikator inferensi atau menyimpulkan apa yang ditulis, indikator situation atau menuliskan hal lain yang telah dipikirkan, indikator clarity atau mengklarifikasi apayang ditulis dan indikator overview atau mengecek semua yang ditulis.

\section{PEMBAHASAN}

Pada tahap memahami masalah, subjek impulsif, awalnya membaca masalah cuma sekali dan belum memahami masalah dan setelah membaca lagi masalah beberapa kali, subjek impulsif baru memahami masalah yang diberikan. Subjek reflektif dari awal sudah membaca masalah beberapa kali dengan seksama dan langsung memehami masalah yang diberikan.

Pada tahap memahami masalah, kedua subjek penelitian telah memenuhi semua indikator kemampuan berpikir kritis dalam memecahkan masalah matematika, yaitu fokus terhadap hal-hal pokok dari masalah yang diberikan, dapat memberikan alasan terhadap apa yang dipahami pada masalah, dapat membuat kesimpulan dari apa yang diapahami pada masalah, memahami semua informasi pada masalah, mengklarifikasi apa yang dipahami dan memeriksa semua apa yang dituliskan sesuai yang dipahami pada masalah.

Pada tahap membuat rencana pemecahan masalah, subjek impulsif tidak d. Tahap Memeriksa Kembali Hasil Pemecahan Masalah

Berdasarkan hasil analisis, dalam memeriksa kembali hasil pemecahan masalah dapat dikatakan bahwa SR memenuhi semua indikator berpikir kritis dalam memecahkan masalah matematika pada tahap memeriksa kembali hasil pemecahan masalah, yaitu indikator memfokuskan pada pengecekan apanyang telah ditulis, indikator memberi alasan tentang apa yang telah diperiksa, indikator menyimpulkan hasil pemeriksaan, indikator memeriksa semua situasi pemecahan masalah, indikator klarifikasi atau penjelasan tambahan dan indikator memeriksa kembali semua hal yang ditulis.

memenuhi semua indikator kemampuan berpikir kritis, yaitu awalnya subjek impulsif belum fokus terhadap hal-hal pokok dari masalah yang diberikan, nanti setelah diberikan pertanyaan tambahan baru subjek impulsif mulai fokus pada hal-hal pokok dari masalah yang diberikan, dapat memberikan alasan terhadap apa yang dipikirkan untuk menyelesaikan masalah, subjek impulsif tidak dapat membuat kesimpulan dari apa yang dipikirkan untuk menjelesaikan masalah, subjek impulsif memahami semua informasi yang dipikirkan pada masalah, subjek impulsif mengklarifikasi apa yang dipikirkan dan subjek impulsif memeriksa semua apa yang dipikirkan. Sedangkan subjek reflektif memenuhi semua indikator kemampuan berpikir kritis, yaitu: indikator fokus memikirkan hal-hal pokok untuk menyelesaikan masalah, indikator reason atau memberi alasan mengenai hal-hal pokok yang dipikirkan, indikator inferensi atau menyimpulkan mengenai apa yang dipikirkan, indikator situation atau 
memikirkan hal lain yang yang terkait dengan masalah, indikator clariti atau mengklarifikasi tetntang apa yang dipikirkan dan indikator overview atau mengecek semua hal yang dipikirkan.

Pada tahap melaksanakan rencana pemecahan masalah, subjek impulsif tidak memenuhi semua indikator kemampuan berpikir kritis, yaitu: Indikator kemampuan berpikir kritis yang dipenuhi adalah fokus menuliskan hal-hal utama atau pokok dari yang telah dipikirkan, mengatakan bahwa semua hal yang dipikirkan sudah ditulis. Indikator yang tidak terpenuhi adalah tidak bisa memberikan alasan tentang apa yang ditulis, tidak dapat menyimpulkan apa yang telah dituliskan, tidak mengklarifikasi tentang apa yang ditulis dan tidak mengecek semua hal yang ditulis. Sedangkan subjek reflektif memenuhi semu indikator kemampuan berpikir kritis dalam memecahkan masalah matematika pada tahap melaksanakan rencana pemecahan masalah, yaitu: indikator fokus pada apa yang ditulis sesuai yang dipikirkan, indikator reason atau memberikaqqn alasan tentang apa yang ditulis, indikator inferensi atau menyimpulkan apa yang ditulis, indikator situation atau menuliskan hal lain yang telah dipikirkan, indikator clarity atau mengklarifikasi apayang ditulis dan indikator overview atau mengecek semua yang ditulis.

Pada tahap memeriksa kembali hasil pemecahan masalah, subjek impulsif tidak memenuhi semua indikator kemampuan berpikir kritis dalam memecahkan masalah matematika, yaitu: indikator kemampuan berpikir kritis yang dipenuhi adalah hanya fokus memeriksa semua hal yang ditulis, sedangkan indicator memberi alasan, menyimpulkan, melihat situasi lain yang diperiksa, mengklarifikasi hal yang diperiksa dan melakukan pengecekan kembali tidak dilakukan. Sujek reflektif memenuhi semuaindikator kemampuan berpikir kritis dalam memecahkan masalah matematika, yaitu: indikator memfokuskan pada pengecekan apanyang telah ditulis, indikator memberi alasan tentang apa yang telah diperiksa, indikator menyimpulkan hasil pemeriksaan, indikator memeriksa semua situasi pemecahan masalah, indikator klarifikasi atau penjelasan tambahan dan indikator memeriksa kembali semua hal yang ditulis.

Terkait dengan kemampuan berpikir kritis, uraian di atas menunjukkan bahwa subjek impulsif tidak cermat/tidak teliti sehingga dalam pengambilan keputusan tidak tepat. Akibatnya pada saat diwawancarai terkait dengan kemampuan berpikir kritisnya tidak memberikan jawaban yang tepat atau bahkan cenderung tidak memberikan jawaban yang tepat. Hal ini sesuai dengan ciri anak impulsif bahwa anak impulsif tidak cermat/tidak teliti sehingga dalam pengambilan keputusan tidak akurat. Hal ini juga sejalan dengan pendapat Goleman (2007) bahwa anak impulsif sistem pemahaman impulsif yang berpengaruh besar adalah pikiran emosional. Lebih lanjut, dikemukakan ciri utama pikiran emosional, yakni respon yang cepat tetapi ceroboh. Pikiran emosional jauh lebih cepat dari pada pikiran rasional, langsung melompat tanpa mempertimbangkan apa yang dilakukannya. Kecepatan itu, mengesampingkan pikiran hati-hati dan analitis yang merupakan ciri khas yang berpikir rasional.

Selanjutnya terkait dengan uraian di atas menunjukkan bahwa subjek reflektif cenderung cermat/teliti dalam berpikir, sehingga dalam pengambilan keputusan lebih akurat. Hal ini sesuai dengan ciri anak reflektif, yaitu cenderung lambat menyelesaikan masalah tetapi dilakukan dengan cermat dan teliti sehingga dalam pengambilan keputusan lebih akurat (Sudia, dkk., 2014).

Kelemahan penelitian ini adalah hasilnya tidak dapat digeneralisasikan, hasilnya hanya berlaku pada subjek yang 
diteliti, akan tetapi dapat dijadikan contoh bagi siswa yang lain, yang memiliki gaya kognitif yang sama dan memiliki permasalah yang sama. Oleh sebab itu

\section{KESIMPULAN DAN SARAN}

Hasil dalam penelitian ini adalah: (1) profil kemampuan berpikir kritis subjek impulsif dalam memecahkan masalah matematika adalah sebagai berikut: (a) tahap memahami masalah adalah subjek impulsif telah memenuhi semua indikator kemampuan berpikir kritis dalam memecahkan masalah matematika, yaitu fokus terhadap hal-hal pokok, dapat memberikan alasan terhadap apa yang dipahami, dapat membuat kesimpulan dari apa yang diapahami, memahami semua informasi pada masalah, mengklarifikasi apa yang dipahami dan memeriksa semua apa yang dituliskan sesuai yang dipahami pada masalah; (b) tahap membuat rencana pemecahan masalah adalah: awalnya subjek impulsif fokus pada hal-hal pokok yang dipikirkan, dapat memberikan alasan terhadap apa yang dipikirkan, tidak dapat membuat kesimpulan dari apa yang dipikirkan, memahami semua informasi yang dipikirkan pada masalah, mengklarifikasi apa yang dipikirkan dan memeriksa semua apa yang dipikirkan; (c) tahap melaksanakan rencana pemecahan masalah adalah: subjek impulsif tidak memenuhi semua indikator kemampuan berpikir kritis, yaitu: hanya fokus menuliskan hal-hal pokok dari yang telah dipikirkan, tidak bisa memberikan alasan tentang apa yang ditulis, tidak dapat menyimpulkan apa yang telah dituliskan, tidak mengklarifikasi tentang apa yang ditulis dan tidak mengecek semua hal yang ditulis; (d) tahap memeriksa kembali hasil pemecahan masalah adalah: tidak memenuhi semua indikator kemampuan berpikir kritis dalam memecahkan masalah matematika, yaitu: hanya fokus memeriksa semua hal yang ditulis, sedangkan indicator lain tidak dipenuhi; dapat dilakukan pengkajian lebih lanjut terkait dengan gaya kognitif dalam memecahkan masalah matematika.

(2) profil kemampuan berpikir kritis subjek reflektif dalam memecahkan masalah matematika adalah sebagai berikut: (a) tahap memahami masalah adalah: fokus terhadap hal-hal pokok, dapat memberikan alasan terhadap apa yang dipahami, membuat kesimpulan dari apa yang diapahami, memahami semua informasi pada masalah, mengklarifikasi apa yang dipahami dan memeriksa semua apa yang dituliskan sesuai yang dipahami pada masalah; (b) tahap membuat rencana pemecahan masalah adalah: fokus memikirkan hal-hal pokok untuk menyelesaikan masalah, memberi alasan mengenai hal-hal pokok yang dipikirkan, menyimpulkan apa yang dipikirkan, memikirkan hal lain yang yang terkait dengan masalah, mengklarifikasi tetntang apa yang dipikirkan, mengecek semua hal yang dipikirkan; (c) tahap melaksanakan rencana pemecahan masalah adalah: subjek reflektif memenuhi semu indikator kemampuan berpikir kritis dalam memecahkan masalah matematika pada tahap melaksanakan rencana pemecahan masalah, yaitu: fokus pada apa yang ditulis sesuai yang dipikirkan, memberikaqqn alasan tentang apa yang ditulis, menyimpulkan apa yang ditulis, menuliskan hal lain yang telah dipikirkan, mengklarifikasi apayang ditulis dan mengecek semua yang ditulis; (d) tahap memeriksa kembali hasil pemecahan masalah adalah: sujek reflektif memenuhi semua indikator kemampuan berpikir kritis dalam memecahkan masalah matematika, yaitu: memfokuskan pada pengecekan apanyang telah ditulis, memberi alasan tentang apa yang telah diperiksa, menyimpulkan hasil pemeriksaan, memeriksa semua situasi pemecahan masalah, mengklarifikasi atau 
memberi penjelasan tambahan dan memeriksa kembali semua hal yang ditulis

Saran dari penelitian yaitu penelitian ini adalah hasilnya tidak dapat digeneralisasikan, hasilnya hanya berlaku pada subjek yang diteliti, akan tetapi dapat dijadikan contoh bagi siswa yang lain,

\section{DAFTAR PUSTAKA}

Anonim. 2007. Pendekatan pemecahan Masalah Matematika

(PengembanganPembelajaran

Matematika). Jakarta: Ditjen-Dikti Depdiknas.

Butts, Thomas. 1980. Posing Problem Property, Problem Solving in School Mathematics. Reston: NCTM.

Cooney, T. J., Davis, E. J, Henderson, K. B. 1975. Dynamics ofTeaching Secondary School Mathematics. Boston: Houghton Mifllin Company.

Dossey, J. A., McCrone, S. S., O’Sulivan, C., \& Gonzales, P. 2006. Problem Solving in the PISA and TIMSS 2003 Assessment. Technical Report: US Department of Education.

Ennis, R.H. 1996. Critical Thinking. New Jersey: Printice-Hall Inc.

Heineman, Peter L. 1995. Cognitive and Learning Style. Boston: Allyn \& Bacon.

Jonassen, D. H. 2004. Learning to Solve Problems and Instructional Design Guide. San Francisco, C. A. Pffeifer.

Kalelioglu, F \& Gulbahar, Y. 2014. The Effect of Instructional Techniques on Critical Thinking an Critical Thinking Dispositions in Online Discussion. Educational Technology and Society, 17 (1): 248-258.

Kirkley, J. 2003. Principle for Teaching Problem Solving. Technical Paper, Plato Learning Inc.

Lau, J.Y F. 2011. An introduction to critical thinking and creativity think yang memiliki gaya kognitif yang sama dan memiliki permasalah yang sama. Oleh sebab itu dapat dilakukan pengkajian lebih lanjut terkait dengan gaya kognitif dalam memecahkan masalah matematika.

more, think better. New Jersey: John wiley \& Sons Inc.

Riding, RJ., Glass, A.,\& Douglas, G. 1993. Individual Differences in Thinking: Cognitive and Neurophysiological Perspectves. Special Issue: Thinking, Educational Psychology, 13 (3 \& 4): 267-279.

Santrock, John W. 2007. Psikologi Pendidikan. Edisi ke Kedua. Jakarta: Kencana Prenada Media Grup.

Saurino, D.R. 2008. Concept Journaling to Increase Critical Thinking Dispositions and Problem Solving Skills in Adult Education. The Journal Of Human Resorce and Adult Learning, 4(1).

Schoenfeld, A., H. 1985. Mathematical Problem Solving. New York: Academic Press. Inc.

Shadiq, Fadjar. 2004. Penalaran, Pemecahan Masalah dan Komunikasi dalam Pembelajaran Matematika. Jakarta: Depdikbud.

Snyder, G.L. \& Snyder, M.J. 2008. Teaching Critical Thinking and Problem Skills. The Delta Pi Epsilon Journal, L( 2).

Stanic, G \& Kilpatrick, J. 1988. Historical Perspectives on Problem Solving in The Mathematics Curriculum, In R. I. Charles \& E. A Silver (Eds). The Teaching and Assesing of Mathematical Problem Solving. Reston: NCTM.

Sudia, Muhammad. 2013. Profil Metakognisi Siswa yang Bergaya 
Kognitif Impulsif-Reflektif dalam Memecahkan Masalah Terbuka Materi Geometri Bangun Datar ditinjau dari Perbedaan Gender. (Disertasi) tidak dipublikasikan, PPS-Unesa, Surabaya.

Sudia, Muhammad, Budayasa, I Ketut, Lukito, Agung. 2014. Profil Metakognisi Siswa yang Bergaya Kognitif Impulsif-Reflektif dalam Memecahkan Masalah Terbuka. Jurnal Ilmu Pendidikan UM Malang.

Stenberg, R.J., Roediger, H.L. \& Halpren, D.F. 2007. Critical Thinking in Psychology. Cambridge: University Press.

Sukmadinata, N.S. 2004. Kurikulum dan Pembelajaran Kompentensi. Bandung: Kesuma Karya Bandung. 